4

\title{
Development and Evaluation of a new Swiss Made SARS-CoV-2 antigen-detecting rapid test

\author{
Ducrest P.J. ${ }^{{ }^{*}}$
} \\ 1 GaDia SA, Route de l'ile aux bois 1A, 1870 Monthey, Switzerland \\ *Corresponding author: GaDia SA, route de l'ile au bois 1A, 1870 Monthey, Switzerland, percevent.ducrest@gadia.net
}

Key words: SARS-CoV-2, COVID-19, antigen, rapid diagnostic test, Lateral Flow immunoassay, Point-of Care Testing

\begin{abstract}
There is an urgent need in rapid diagnostic test (RDT) to detect antigen of SARS-CoV-2 to reduce the spread of COVID-19 outbreak. We have developed a rapid and simple point-of-care lateral flow immunoassay (LFIA) detecting nucleocapsid antigen of SARS-CoV-2 in 10 minutes. The aim of this study is to evaluate the diagnostic performance and analytical sensitivity of this RDT. RT-PCR positive nasopharyngeal swab samples $(n=20)$ for SARS-CoV-2 and 40 negative control samples were studied. Analytical sensitivity was assessed using Gamma-irradiated SARS-CoV-2 and the limit of detection (LOD) was determined at $1.4 \times 10^{2} \mathrm{TCID}_{50} / \mathrm{ml}$. Overall, RDT diagnostic sensitivity was $90 \%$ (95\% confidence interval [95\%CI]: 67-98\%) and specificity 98\% (95\% CI: $85-100 \%)$. The sensitivity was $100 \%$ (95\% CI: 75-100\%) when using only samples with a RT-PCR Cycle threshold lower than 30 . This antigen RDT displays a high diagnostic accuracy for SARS-CoV-2 antigen detection in high COVID19 prevalence settings. Its use could be considered in the absence of routine RT-PCR facilities such in low-income countries.
\end{abstract}


medRxiv preprint doi: https://doi.org/10.1101/2021.03.25.21252280; this version posted March 26, 2021. The copyright holder for this preprint (which was not certified by peer review) is the author/funder, who has granted medRxiv a license to display the preprint in It is made available under a CC-BY-ND 4.0 International license .

44

45

46

47

48

49

50

51

52

53

54

55

56

57

58

59

60

61

62

63

64

65

66

67

68

69

70

71

72

73

\section{Introduction}

The COVID-19 pandemic is a challenge for the population, healthcare systems and manufacturer of medical devices. The easy and rapid detection of infected patient is crucial to shorten the spread of the SARS-CoV-2. The actual gold standard for the diagnostic of COVID-19 is the reverse-transcription Polymerase Chain Reaction (RT-PCR) but has certain inconveniences such as the time, laboratory and equipment needed. Such analyses can difficulty be implemented in low-income countries where laboratory or trained staff are missing [1-3].

Rapid antigen tests are lateral flow immunoassay with a visual (gold nanoparticles) or fluorescent detection. Since the beginning of the COVID-19 outbreak, thousands of rapid tests have been listed on the COVID-19 Testing pipeline of the Find Foundation (Geneva, Switzerland). Most of the test are produced in Asia.

Recent studies highlighted a lower sensitivity compared to RT-PCR [4, 5]. However, the most common rapid antigen test such as Panbio (Abbott), Standard Q (SD Biosensor, Roche Diagnostics) and BD Veritor (Beckton \& Dickinson) are the most studied and published tests. Based on a meta-analysis of available performances data, the overall sensitivity for Panbio (Abbott) is $79 \%$ and the specificity is 99\% ( $\mathrm{n}=10936$ ). For the Standard Q (SD Biosensor, Roche Diagnostics), the overall sensitivity is $85 \%$ and specificity $99 \%$ ( $n=2892)$. Finally, the BD Veritor (Beckton \& Dickinson) has an overall sensitivity of $91 \%$ and a specificity of $99 \%(n=964)$ [6-9]. It has been noted that the sensitivity increases with high viral load (RT-PCR Cycle threshold < 30). The World Health Organization $($ WHO) published a target product profile with the minimal and desirable analytical and clinical performances (TPP WHO) [10]. The WHO recommended that an Ag-RDT test must have a sensitivity of at least $80 \%$ and a sensitivity of at least $97 \%$, based on the gold-standard RT-PCR test. The analytical performance must be at least $10^{6}$ genomic copies/ml (CT 25-30).

A patient with a positive Ag-RDT result within 5 days after symptom onset can be considered to have a SARS- CoV-2 infection, because these individuals are more likely to have high viral loads [11]. However, a negative result must be interpreted with caution due to reduced sensitivity with low viral load and a confirmation test (RT-PCR) is recommended [10].

Here we have developed and evaluated a new rapid antigen-detecting test following the last recommendation of the WHO. Both analytical performance and clinical performances have been evaluated.

6

9


Material \& Methods

\section{3}

84

85

86

87

\section{Study population and swab sample collection}

Anonymized leftovers of frozen Nasopharyngeal swab specimen, discharged in medium Tris EDTA 1X, supplied by INO Specimens BioBank, ISB (Clermont-Ferrand, France), were used for the evaluation. A total of 60 samples, including 40 negative and 20 positive samples were all evaluated with CE-IVD \& EUA-FDA reference RT-PCR Nucleic Acid Diagnostic Kit (Sansure Biotech Inc, Changsha, China) on the QuantStudio 7 Pro Real-Time PCR Systems Instrument (Termofisher Scientific, Waltham, USA). The positive samples were classified according to the Cycle Threshold (CT) for both probe orfl $a b$ and $N$ gene. The cut-off values for RT-PCR CT were $<39.00$ for positive samples and $>42.00$ for negative samples.

\section{Inactivated SARS-CoV-2 and recombinant proteins}

SARS-Related Coronavirus 2, Isolate USA-WA1/2020, Gamma-Irradiated and Heat-inactivated were supplied by BEI Resources. Recombinant SARS-CoV-2 Nucleocapsid protein was supplied by GenScript Biotech (Netherlands) B.V. (Leiden, NL). Tenfold dilution was prepared in the running buffer of the test and evaluated in triplicates. The limit of detection is defined as the lowest concentration were the signal intensity is egal or greater than 2 Rann score value (BBI, UK).

\section{Antigen Rapid test}

The Antigen-detecting rapid test COVIDia-Antigen was developed and manufactured in Switzerland by GaDia SA (Monthey, Switzerland). This test detects the nucleocapsid antigen in nasopharyngeal and throat swabs. The test has two pre-coated lines on a nitrocellulose membrane, one Control line (C) and one Test line (T). The test line is composed of rabbit monoclonal anti-nucleocapsid antibody. The gold nanoparticles (Nanocomposix, San Diego, USA) are coated with rabbit anti-Nucleocapsid antibodies. The control line (C) is composed of a goat anti-rabbit antibody (Jackson ImmunoResearch Europe, Ely, UK). When a positive sample flows through the test membrane, the anti-SARS-CoV-2 antibodies present on the membrane (Test line) capture the antigen and form a colored conjugate complex on the test line. The control line captures the excess of gold conjugate nanoparticles and forms a red line.

\section{Sample Testing}

The pouched test was opened immediately before use. To perform the test, $60 \mu \mathrm{L}$ of defrosted Nasopharyngeal swab sample was diluted in $60 \mu \mathrm{L}$ of running buffer according to the manufacturer instructions. Then, $100 \mu \mathrm{L}$ were added to the sample hole and the test was read after 15 minutes. For the limit of detection using inactivated SARS-CoV-2, the sample was directly diluted in running buffer and $100 \mu \mathrm{L}$ were added to the test as describe above. 
medRxiv preprint doi: https://doi.org/10.1101/2021.03.25.21252280; this version posted March 26, 2021. The copyright holder for this preprint (which was not certified by peer review) is the author/funder, who has granted medRxiv a license to display the preprint in It is made available under a CC-BY-ND 4.0 International license.

118

119

120

121

122

123

124

125

126

\section{Results}

128

129

130

131

132

133

134

135

136

137

138

139

140

141

142

143

144

145

146

147

148

149

150

151

\section{Statistics} 21.5-30.2).

Vassarstats online tool (www.vassarstats.net) was used to calculate sensitivity (SE), specificity (SP), positive and negative predictive values (PPV, NPV), 95\% confidence intervals, median, and Interquartile range (IQR); while significance (p-values) was calculated using Mann-Whitney U test for categorical variables. Statistical significance was defined as $\mathrm{p}<0.05$.

\section{Baseline characteristics}

The baseline demographic characteristics of patients' samples were as follows: the 20 RT-PCR confirmed COVID-19 samples from patients were older (median 63 years old, IQR 44-80.75) compared to the healthy plasma samples patients $(\mathrm{n}=40)$ (median 51 years old, IQR 39-70.75; $\mathrm{p}<0.05$ ). The proportion of females in COVID-19 cohort was $75 \%(n=15)$ and $43 \%(n=17)$ in negative control group. The median CT value for $N$ gene probe is 25.03 (IQR 20.1-30.6) and for orfl $a b$ probe is 26.8 (IQR

\section{Specificity of Antigen RDT on negative control group}

Antigen RDT diagnostic specificity (percent negative agreement, PNA) against negative control group $(n=40)$ is shown in Table 1. Antigen RDT revealed concordant results in 39 of 40 samples. Only one discordant result showed a low positive signal, while being negative (false-positive). These resulted in an Antigen RDT specificity (SP) of 97.5\% (95\% CI: 85.3-99.9\%).

\section{Sensitivity of Antigen RDT against RT-PCR confirmed COVID-19 samples}

Antigen RDT diagnostic sensitivity (percent positive agreement, PPA) against RT-PCR confirmed samples $(n=20)$ is shown in Table 1. Antigen RDT revealed concordant results in 18 of 20 samples. Only 2 samples, with a CT value $>30$ were negative (false-negative). These results indicate an Antigen RDT sensitivity (Se) of $90.0 \%$ (95\% CI: 66.9-98.2\%). When considering samples with a CT $<30$, the sensitivity is $100 \%$ (95\% CI: $74.7-100 \%)$. The table 2 indicate the Sensitivity or PPA compared to CT values of samples. 
medRxiv preprint doi: $h t t p s: / / d o i . o r g / 10.1101 / 2021.03 .25 .21252280$; this version posted March 26, 2021. The copyright holder for this preprint (which was not certified by peer review) is the author/funder, who has granted medRxiv a license to display the preprint in It is made available under a CC-BY-ND 4.0 International license.

153

154

155

156

157

158

159

160 The two false-negative samples have a $\mathrm{CT}$ value ( $\mathrm{N}$ gene) of respectively 31.05 and 35.01 visible on red
Table 1: Diagnostic performance of antigen RDT

\begin{tabular}{|c|c|c|c|c|}
\hline & \multicolumn{3}{|c|}{ RT-PCR } \\
\hline & & Positive & Negative & Total \\
\hline \multirow{3}{*}{ COVIDia-Antigen } & Positive & 18 & 1 & 19 \\
\hline & Negative & 2 & 39 & 41 \\
\hline & Total & 20 & 40 & 60 \\
\hline \multicolumn{2}{|c|}{ Sensitivity } & \multicolumn{3}{|c|}{$90.0 \%\left(\mathrm{CI}_{95 \%}: 66.9-98.2 \%\right)$} \\
\hline \multicolumn{2}{|c|}{ Specificity } & \multicolumn{3}{|c|}{$97.5 \%\left(\mathrm{CI}_{95 \%}: 85.3-99.9 \%\right)$} \\
\hline \multicolumn{2}{|c|}{ PPV } & \multicolumn{3}{|c|}{ 94.7\% (CI $95 \%: 71.9-99.7 \%)$} \\
\hline \multicolumn{2}{|l|}{ NPV } & \multicolumn{3}{|c|}{$95.1 \%\left(\mathrm{CI}_{95 \%}: 82.2-99.2 \%\right)$} \\
\hline
\end{tabular}

Table 2: Percent positive agreement of the antigen RDT at different RT-PCR CT values.

\begin{tabular}{|c|c|}
\hline CT values & $\begin{array}{c}\text { Percent positive agreement } \\
\text { (CI95\%) }\end{array}$ \\
\hline$<20$ & $100 \%(46.3-100 \%)$ \\
\hline $20-25$ & $100 \%(46.3-100 \%)$ \\
\hline $25-30$ & $100 \%(46.3-100 \%)$ \\
\hline$<30$ & $100 \%(74.7-100 \%)$ \\
\hline$>30$ & $60.0 \%(17.0-92.7 \%)$ \\
\hline overall & $90.0 \%(66.9-98.2 \%)$ \\
\hline
\end{tabular}
the CT value, the highest the signal intensity. Based on the regression done on the 20 positive samples (figure 1), R-squared was 0.82 and the LOD with a Rann value of 2 can be estimated at a RT-PCR CT value of 31.5 .

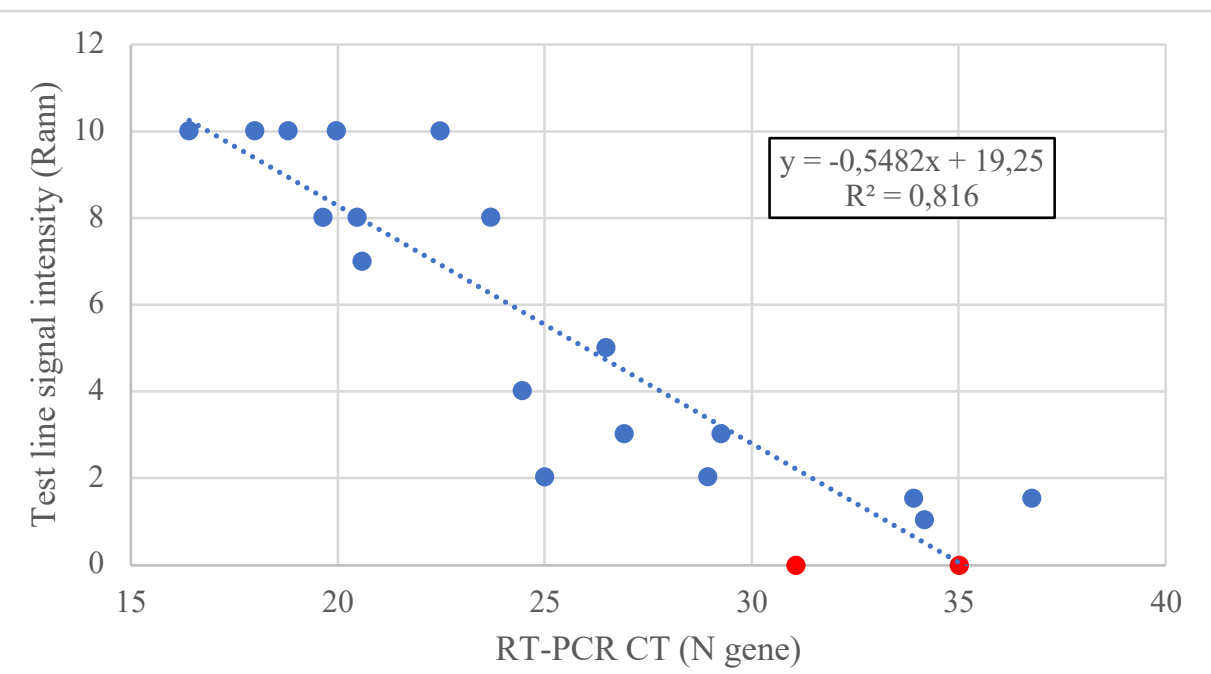

Figure 1 : Test line intensity of the antigen RDT compared to the CT value of RT-PCR (N gene). Blue dots represent true-positive samples and red dots false-negative results 
medRxiv preprint doi: https://doi.org/10.1101/2021.03.25.21252280; this version posted March 26, 2021. The copyright holder for this preprint (which was not certified by peer review) is the author/funder, who has granted medRxiv a license to display the preprint in It is made available under a CC-BY-ND 4.0 International license .

169

170

171

172

173

174

175

176

177

178

179

180

181

182

183

184

185

186

187

188

189

190

191

192

193

194

195

196

\section{Analytical Sensitivity of Antigen RDT}

The analytical sensitivity of the Rapid diagnostic test was evaluated using Gamma-irradiated SARSCoV-2 (Isolate USA-WA1/2020) from BEI Resources. The irradiated SARS-CoV-2 was diluted in running buffer and tested with rapid test 5 times. The LOD was defined as a signal intensity of 2 Rann score value on all 5 replicates. The table below (table 3 ) give the results of the LOD evaluation. The LOD of the Rapid test was defined at $1.4 \times 10^{2} \mathrm{TCID} 50 / \mathrm{ml}$, corresponding to $7.9 \times 10^{4}$ genome equivalent $/ \mathrm{ml}$.

Table 3: Limit of detection of the antigen RDT using Gamma-irradiated SARS-CoV-2

\begin{tabular}{|c|c|c|c|c|c|c|}
\hline SARS-CoV-2 strain & \multicolumn{6}{|c|}{$\begin{array}{c}\text { Gamma-Irradiated SARS-CoV-2, Isolate USA-WA1/2020 } \\
\text { [BEI Resource, ref. NR-52287, Lot. 70039067] }\end{array}$} \\
\hline Stock titer $\left(\mathrm{TCID}_{50} / \mathrm{ml}\right)$ & \multicolumn{6}{|c|}{$2.8 \times 10^{6}$} \\
\hline $\begin{array}{l}\text { Stock titer (genome } \\
\text { equivalent } / \mathrm{ml} \text { ) }\end{array}$ & \multicolumn{6}{|c|}{$1.57 \times 10^{9}$} \\
\hline Dilution & $1 / 10$ & $1 / 100$ & $1 / 1000$ & $1 / 10000$ & $1 / 20000$ & $1 / 40000$ \\
\hline $\begin{array}{l}\text { Concentration in dilution } \\
\left(\mathrm{TCID}_{50} / \mathrm{ml}\right)\end{array}$ & $2.8 \times 10^{5}$ & $2.8 \times 10^{4}$ & $2.8 \times 10^{3}$ & $2.8 \times 10^{2}$ & $1.4 \times 10^{2}$ & $7.0 \times 10^{1}$ \\
\hline $\begin{array}{l}\text { Concentration in dilution } \\
\text { (genome equivalent } / \mathrm{ml} \text { ) }\end{array}$ & $1.6 \times 10^{8}$ & $1.6 \times 10^{7}$ & $1.6 \times 10^{6}$ & $1.6 \times 10^{5}$ & $7.9 \times 10^{4}$ & $3.9 \times 10^{4}$ \\
\hline Siagnal intensity (Rann) & 10 & 6 & 4 & 3 & 2 & 1 \\
\hline Replicates & $100 \%(5 / 5)$ & $100 \%(5 / 5)$ & $100 \%(5 / 5)$ & $100 \%(5 / 5)$ & $100 \%(5 / 5)$ & $60 \%(3 / 5)$ \\
\hline
\end{tabular}

\section{Discussion}

The key finding of the present evaluation study, using an unmatched case-control study including $33.3 \%$ of negative control samples, is that the diagnostic accuracy of antigen RDT on frozen nasopharyngeal swabs when using RT-PCR as reference method, displayed a Percent positive agreement (Sensitivity) of $90.0 \%$, a SP of $97.5 \%$, a PPV of $94.7 \%$ and a NPV of $95.1 \%$. These results are considered as desirable for the sensitivity and acceptable for the specificity according to the Target Product Profile of the WHO.

The two false-negative results obtained with this RDT had a RT-PCR CT value bigger than 30, such samples have less viral load. The analytical sensitivity of this RDT was defined at $1.4 \times 10^{2} \mathrm{TCID}_{50} / \mathrm{ml}$, corresponding to $7.9 \times 10^{4}$ genomic copies/ml (Table 3 ). The analytical sensitivity based on RT-PCR CT value, was also extrapolated using the 20 positive samples (figure 1) and was defined at a CT value of 31.5. The TPP from WHO defined an analytical sensitivity of at least 30 cycle threshold (CT) values [10]. A Point-of-Care (POC) test that can consistently detects the most infectious patients, with high viral load of at least $10^{6}$ genomic copies/ml, in order to interrupt transmission. This RDT fulfills the TPP of the WHO in term of sensitivity and specificity. The diagnostic sensitivity is comparable to the SD Biosensor and Abbott Panbio rapid antigen tests $[7,8]$. 
medRxiv preprint doi: https://doi.org/10.1101/2021.03.25.21252280; this version posted March 26, 2021. The copyright holder for this preprint (which was not certified by peer review) is the author/funder, who has granted medRxiv a license to display the preprint in

It is made available under a CC-BY-ND 4.0 International license .

198 Such performances indicate that this RDT could be fit for purpose in clinical settings where a high 199 prevalence of COVID-19 prevails, especially in situations where RT-PCR are not available or cannot 200 be reliably used. Diagnostic performances in low prevalence populations still needs to be determined 201 and larger populations need to be tested. In addition, it is clear that antigen assay for SARS-CoV-2 need 202 to be performed in the first week after symptoms onset $[6,12]$. Finally, here we used frozen 203 nasopharyngeal swab specimens and the test was performed in a laboratory environment; we may expect different results in real-life at patients' bed and using fresh nasopharyngeal swab.

In addition, the test provided clear results, without indeterminate or invalid results (no Control line). There are several limitations to this study. First, we present here the results of a method evaluation study and not a seroprevalence study. Therefore, the PPV obtained here (based on a 33.3\% proportion of cases defined as laboratory confirmed SARS-CoV-2 by RT-PCR) will probably be lower in a low prevalence setting. Another limitation of this validation study lies in its limited sample size leading to broad $95 \%$ confidence intervals, requiring confirmation of these data at a larger scale. Finally, our present conclusions only apply to this RDT, and must not be applied to any other RDTs currently available.

In conclusion, this RDT is not meant to replace a SARS-CoV-2 RT-PCR but could be a reliable option for quickly assessing the presence of SARS-CoV-2 antigen in moderate to high COVID-19 prevalence settings and when high viral loads are expected, especially in situations where a rapid result is needed or where RT-PCR is not available. Further investigations in low prevalence situations and using capillary blood are necessary.

\section{Conflicts of Interest:}

222 PJD is the CEO of GaDia SA, the developer and manufacturer of this RDT. This study was funded by GaDia SA, Switzerland.

\section{References}

1. Chaimayo, C., Kaewnaphan, B., Tanlieng, N. et al. Rapid SARS-CoV-2 antigen detection assay in comparison with real-time RT-PCR assay for laboratory diagnosis of COVID-19 in Thailand. Virol J 17, 177 (2020). https://doi.org/10.1186/s12985-020-01452-5Krüger

2. Colavita et al., COVID-19 Antigen Rapid Test as Screening Strategy at the Points-of-Entry: Experience in Lazio Region, Central Italy, August-October 2020, medRxiv 2020.11.26. 20232728; doi: https://doi.org/10.1101/2020.11.26.20232728

3. Fitzpatrick et al. Buyer beware: inflated claims of sensitivity for rapid COVID-19 tests, The Lancet, Volume 397, Issue 10268, 2021

4. Haage et al., Impaired performance of SARS-CoV-2 antigen-detecting rapid tests at elevated temperatures, medRxiv 2021.01.06.21249314; doi: https://doi.org/10.1101/2021.01. 06.21249314 
medRxiv preprint doi: https://doi.org/10.1101/2021.03.25.21252280; this version posted March 26, 2021. The copyright holder for this preprint (which was not certified by peer review) is the author/funder, who has granted medRxiv a license to display the preprint in It is made available under a CC-BY-ND 4.0 International license .

5. Linares et al., Panbio antigen rapid test is reliable to diagnose SARS-CoV-2 infection in the first 7 days after the onset of symptoms, Journal of Clinical Virology, 133, 2020

6. Hayer et al., Real-world clinical performance of commercial SARS-CoV-2 rapid antigen tests in suspected COVID-19: A systematic meta-analysis of available data as per November 20, 2020, medRxiv 2020.12.22.20248614; doi: https://doi.org/10.1101/2020.12.22.20248614

7. Corman et al., Comparison of seven commercial SARS-CoV-2 rapid Point-of-Care Antigen tests, medRxiv 2020.11.12.20230292; doi: https://doi.org/10.1101/2020.11.12.20230292

8. Lindner et al. SARS-CoV-2 patient self-testing with an antigen-detecting rapid test: a head-tohead comparison with professional testing, medRxiv 2021.01.06.20249009; doi: https://doi.org/10.1101/2021.01.06.20249009

9. World Health Organization, Target product profiles for priority diagnostics to support response to the COVID-19 pandemic v.1.0, 28 September,2020, Geneva, Switzerland

10. Masia et al., Nasopharyngeal Panbio COVID-19 antigen performed at point-of-care has a high sensitivity in symptomatic and asymptomatic patients with higher risk for transmission and older age, Open Forum Infectious Diseases, 2021; ofab059, https://doi.org/10.1093/ofid/ofab059

11. Pekosz et al., Antigen-Based Testing but Not Real-Time Polymerase Chain Reaction Correlates With Severe Acute Respiratory Syndrome Coronavirus 2 Viral Culture. Clin Infect Dis. 2021 Jan 20:ciaa1706. doi: 10.1093/cid/ciaa1706. Epub ahead of print. PMID: 33479756. 